\title{
Optimizing the Cooperation Between Teacher and Parents in the Implementation of Studying From Home for Early Childhood
}

\author{
Nini Aryani ${ }^{\boxminus}$, Nopa Wilyanita² \\ DOI: $10.35445 /$ alishlah.v13i3.965
}

\begin{tabular}{l}
\hline Article Info \\
\hline Keywords: \\
Learning from Home; \\
Learning Cooperation; \\
Early Childhood
\end{tabular}

Kata kunci:

Belajar dari rumah;

Kerjasama dalam

belajar;

Anak usia dini

\begin{abstract}
Early childhood education is being conducted at home in the event of a Covid-19 pandemic. Parents in the WhatsApp Group receive teaching materials from the teacher via this method of instruction. As a result, teachers and parents must work together to ensure that children at home are still receiving an education that is tailored to their individual needs. This study used a qualitative approach based on interviews with teachers and parents from five Aisyiyah Bustanul Athfal Kindergartens located in Pekanbaru City. In the study, teachers and parents found that a positive attitude in communication patterns between them. They can lead to good patterns of cooperation, with parents being able to guide and motivate their children while implementing learning at home and being directly involved in learning with children by accompanying their children while studying.
\end{abstract}

\begin{abstract}
Abstrak
Di masa pandemi Covid-19, pembelajaran untuk anak usia dini dilakukan dari rumah. Dalam pembelajaran ini, guru mengirimkan bahan ajar untuk anak melalui aplikasi Grup WhatsApp yang terdiri dari orang tua. Untuk itu diperlukan dukungan dan kerjasama antara guru dan orang tua agar anak di rumah tetap mendapatkan pembelajaran yang sesuai dengan kondisi dan perkembangannya. Penelitian ini menggunakan metode kualitatif dimana pengumpulan data dilakukan melalui wawancara terstruktur dengan guru dan orang tua siswa dari 5 TK Aisyiyah Bustanul Athfal di Kota Pekanbaru. Hasil penelitian menemukan bahwa pola kerjasama yang baik antara guru dan orang tua dapat dicapai dengan menunjukkan sikap positif dalam pola komunikasi antara guru dan orang tua dimana orang tua harus memiliki kemampuan untuk membimbing dan memotivasi anak selama pelaksanaan pembelajaran dari rumah dan terlibat langsung dalam belajar bersama anak dengan mendampingi anak saat belajar.
\end{abstract}

\section{INTRODUCTION}

The Covid-19 pandemic has caused a number of serious problems around the world, including in Indonesia. There is a direct correlation between pandemics and the education system. It is possible for educators to use a wide range of applications to support the learning process and to report on the progress of students. Attempts by the government to limit educational activities have slowed the spread of Covid-19, according to those efforts. The Ministry of Education and Culture issued a regulation on learning at home in response to this (LFH). The Covid-19 pandemic makes learning from home (LFH) viable for all early childhood education programs (PAUD). The Ministry of Education and Culture's Circular Letter Number 4 of 2020, dated March 24, 2020, has made it possible for all levels of education,

\footnotetext{
${ }^{1}$ STKIP Aisyiyah Riau, Pekanbaru, Indonesia $₫$

Email: nini.aryani@gmail.com

${ }^{2}$ STKIP Aisyiyah Riau, Pekanbaru, Indonesia

Email:nwilya@gmail.com
} 
including PAUD, to learn at home or online. Mutual respect and intimacy between teachers and students have been fostered since the introduction of PAUD (Ariyani, 2016; Satrianingrum, Yulsyofriend, Ismet, 2020; and Pramana 2020). Online learning or BDR has changed the traditional learning pattern of parents helping their children learn at home instead of face-to-face with the teacher.

Educators aren't unfamiliar with online learning activities. Indeed, many teachers are still unfamiliar with the online learning system, especially those at PAUD schools, who prefer to conduct learning or play directly in front of their students and interact with the classroom environment. Because this LFH system cannot be used in early childhood without the assistance of parents, it is impossible to separate the involvement of parents as companions and guides in learning that is carried out by PAUD teachers (Kusmana; 2011). Parents have an important role in the implementation of LFH. This is because the teacher is only limited to transferring material or assignments through parents, which the child must then do at home. Unfortunately, not all PAUD institutions feel that the collaboration between teachers and parents runs optimally, especially with parents who have careers. The teacher feels many obstacles so that collaboration with parents does not work as it should and is far from what is expected. Several factors cause it, including limited time for working parents, lack of understanding of technology, lack of parental creativity, and so on. All of these problems will impact children's development, which includes cognitive, physical, motor, language, and social-emotional development.

The cooperation of teachers and parents in implementing LFH is the key to the success of the learning objectives themselves. The role of parents is the first and eternal educator. When parents and practitioners work together in early childhood settings, the results will positively impact children's development and learning. On this basis, every teacher in the educational setting should try as optimally as possible to develop effective collaboration (Peter Clough. 2015) with parents. Another challenge PAUD institutions face apart from the suboptimal cooperation with parents is that most of thePAUD institutions face apart from the suboptimal cooperation with parents. Most parents prefer that their children study face-to-face, not BDR. The results of a survey of several parents and PAUD teachers found that the collaboration between teachers and parents was still limited to sending assignments for children from teachers to parents via WhatsApp. In other words, no two-way communication occurs. Some working parents can only accompany their children in the afternoon or evening, so it is difficult to motivate children to study because they feel tired from their activities starting from morning to evening. Some parents have signal disturbances, so that they are slow in getting information about the learning materials sent by the teacher. Not a few parents want their children and teachers to learn faceto-face at school. Summarizing the various problems that arise from learning from home, it is necessary to optimize the cooperation of teachers and parents so that learning can run optimally and effectively.

Optimizing teacher and parent cooperation in implementing learning from home (BDR) for early childhood during the COVID-19 pandemic is based on the Ministry of Education and Culture's LFH guidelines No. 15 of 2020, which mentions the importance of the role of educators and parents in online learning. Based on this reference, there will be four types of collaboration that need to be carried out by teachers and parents of students who will be reviewed in this study. The first collaboration is the need for a positive attitude in the pattern of communication between teachers and parents in the implementation of LFH. In contrast, the second is the ability of parents to guide and motivate children for the implementation of LFH. The third collaboration is the involvement of parents in learning or playing with their children, and the fourth is the positive attitude of parents in assisting children in doing the tasks given by the teacher. Good cooperation is cooperation that supports each other, trusts each other, and is responsible for the tasks assigned by the team to realise the team's goals.

Thus, forming interpersonal communication includes openness, empathy, supportive behaviour, positive behaviour, and equality. Likewise, educating early childhood requires sufficient knowledge, ability, and practical experience to support a personality (Masnipal, 2013). One of the important elements in this effort is the collaboration between teachers and parents in which these two elements must be able to enter the child's world. The world of children is very complex, so that knowledge and skills are needed so that children's needs can be fully met. Based on some of the opinions described 
above, it can be concluded that cooperation is a business or activity that is carried out together to achieve a good goal and is interconnected in carrying out common tasks. In this case, the collaboration in question is a cooperation between teachers and parents, precisely in learning from home, which requires teachers and parents of students.

Parents of students have a very big role in children's ability in the educational environment. The role of parents is also very necessary to provide education to children in online learning as a substitute for teachers at home in terms of guiding, motivating, facilitating, and supporting the implementation of learning. According to (Menheere \& Hooge, 2010), parental involvement is important because parents tend to have a great influence on children's success. With the involvement of parents, children will be helped in developing their literacy, intellectual, motivation, and achievement abilities.

Parental involvement is critical when learning at home because it motivates children to complete learning activities assigned or assigned by the teacher. According to Lilawati's opinion (2020), parental involvement in supporting learning activities at home during the Pandemic includes the following: 1) parents believe that learning at home is effective because the tasks assigned by teachers are completed by children with the assistance and guidance of parents at home; 2) learning facilities at home are still considered capable of increasing the level of learning at home, despite the fact that some parents believe that the learning system at home is ineffective. According to some obtained opinions, parents have the responsibility and obligation to pay attention to, care for, and direct their children by the mandate.

\section{METHOD}

This study used a qualitative approach. The study was conducted as a case study with an analysis unit consisting of five Aisyiyah Bustanul Athfal Kindergartens located throughout Pekanbaru City. Suharsimi Arikunto's (2005; 131) definition of a case study is that it is an intensive, detailed, and indepth examination of an organization, institution, or particular phenomenon. According to the area, case research is limited to a very specific area or subject. Case research, on the other hand, is more indepth in nature when viewed through the lens of the investigation. This study establishes a collaborative pattern between teachers and parents who can contribute to the implementation of LFH for early childhood learning. Structured interviews were used to collect data by creating several questions and then distributing them to respondents, teachers and parents, via Google Forms.

The research was carried out from February to June 2021. Data collection was carried out by interviewing 18 teachers and 83 parents from 5 Aisyiyah Bustanul Athfal Kindergartens, namely, TK $\mathrm{ABA}$ 2, TK ABA 3, TK ABA 4, TK ABA 5, and TK ABA 7. These five kindergartens are schools that implement BDR out of 10 ABA kindergartens in Pekanbaru City. Structured interviews were conducted by providing several questions answered by respondents via a google form. The choice of this method was because the Covid rate in Pekanbaru City was still high where Pekanbaru city was in the red zone, so it was not possible to hold face-to-face interviews. This study conducted structured interviews with teachers and parents referring to the Ministry of Education and Culture's LFH Guidelines No. 15 of 2020 as follows:

\begin{tabular}{|c|c|c|}
\hline No & Indicator & Sub Indicator \\
\hline 1 & The role of educator & $\begin{array}{l}\text { Making mechanism for communication } \\
\text { between parents and teacher } \\
\text { Assuring the learning process runs well } \\
\text { Coordination between teacher and parents } \\
\text { Collecting and recapping the assignment sent } \\
\text { by parents }\end{array}$ \\
\hline 2 & The role of parents & $\begin{array}{l}\text { Approving the communication way with the } \\
\text { school party } \\
\text { Assuring the kids ready to follow the learning } \\
\text { Preparing the time to support the online } \\
\text { learning process } \\
\text { Encouraging the kids to be active during the } \\
\text { learning process }\end{array}$ \\
\hline
\end{tabular}


Based on the above instrument, the role of parents can be categorized into the ability to guide and motivate children for BDR learning, involvement in learning/playing with children, and a positive attitude in assisting children in carrying out assignments from the teacher.

\section{FINDINGS AND DISCUSSION}

Structured interviews that have been conducted with 18 teachers and 83 parents found various responses to the implementation of learning from home. The results of the structured interviews obtained will be described in this section. The average respondent's answer regarding the agreement for a communication system through WAG (WhatsApp Group) between teachers and parents before LFH learning is carried out is Yes. Teachers provide important information besides being part of children's learning through WAG. Communication between teachers and parents runs smoothly through the IT application (WAG). Communication between parents and teachers or the school, apart from WhatsApp, is also done by telephone. This finding indicates a positive attitude in communicating so that it will encourage two-way communication between teachers and parents.

A positive attitude in communicating between teachers and parents in implementing LFH is very necessary. The most important aspect of the learning process is good communication. WAG (WhatsApp Group) is a medium of communication and learning used as long as the home learning system is implemented. The teacher in this case not only gives or sends assignments to the WAG (WhatsApp Group) which consists of all parents, but also needs to build communication, such as asking how the students are in the morning, asking how the parents are, and even opening a consultation session with parents regarding learning. In addition, the teacher also provides information regarding things that parents can do to guide and motivate children while learning from home so that in this positive attitude, the meaningful role of teachers and parents will appear in the implementation of LFH learning.

Education and Culture's LFH Guidelines No. 15 of 2020 regarding the Role of Educators and Parents in Online Learning states educators should facilitate distance learning online, offline or a combination of both following the conditions and availability of learning facilities; make mechanisms to communicate between parents and students; contact parents to discuss appropriate lesson plans; and provide information to students and their families about their progress. This includes making sure that students' children can take part in learning at home, preparing time to help children learn at home, encouraging participation; submitting activity sheets, and agreeing on communication channels with the school. Delivering lessons on time to the classroom. This is a situation where the parent's role is to serve as a facilitator.

Parents must send completed worksheets to the teacher. However, some children are occasionally late with their assignments because their parents determined that the children's condition at the time indicated a lack of interest in learning, resulting in the failure to complete the teacher's assigned tasks. Parents must continue to communicate these conditions to teachers so that teachers have a picture of the conditions and obstacles parents and students face at home. Parents in LFH need always to make sure that their children have followed the learning programmed by the teacher. Parents, in this case, observe children when participating in learning activities and ensure that children have carried out learning activities according to teacher instructions. Parents apply children's study hours at home. However, not infrequently, learning hours adjust to the conditions of each parent. This condition shows that cooperation between parents and teachers is needed. Before providing learning activities sent by the teacher to children, parents first need to make sure that the child is ready. Apart from that, parents must also understand if there are difficulties experienced by children while studying or doing assignments from the teacher.

In cases like this, the role of parents is needed in motivating children to be ready to carry out learning. The role of parents is needed in the implementation of learning from home. When parents have an active role, it can be said that parents and teachers have cooperated. This is in line with the research results of Oktaria, Putra, 2020; Wardati, 2020; who concluded that the key to successful 
learning from home is the collaboration between parents and teachers. Both have a very important role. In line with Oni Taliawo (2019), it is stated that the form of cooperation between parents and teachers greatly determines children's interest in learning. One of the efforts that teachers and parents can make is to motivate children. Haerudin (2020) added that the role of parents in the online learning process will indirectly strengthen the relationship between parents and children.

Parents have made various efforts to motivate children to always follow the learning programmed by the teacher properly, with pleasure and without coercion or pressure.BDR that is implemented optimally requires the role of parents considering the learning patterns of all children are not the same. Through the role of parents, teachers will find it easier to provide direction to parents to motivate children when they are going to do the BDR process. In line with Nursina's research (2016: 4), it is stated that Learning patterns are one of the important factors that greatly influence student achievement or learning outcomes. It is often known in education that students have different learning patterns from one another. Learning patterns at home are influenced by children's learning motivation, which requires the role of parents who can assist educators in managing the learning process from home.

Motivating children is a very important activity during learning carried out from home, especially motivation from parents. Parents have done various things to encourage children to take part in learning and do assignments well without feeling pressured. One way to motivate children that parents can do is by giving rewards to children. In terms of motivating, teachers also have the same role. Motivating students can be done by holding virtual meetings with children in which guidance and motivation will be given from teachers so that children remain enthusiastic about learning with joy. The role of parents in learning is very important, as found in research (Lilawati, 2020) which concluded that the role of parents includes various initiatives and adjustments to specially designed learning programs. Thus, parents will feel that learning done at home is effective because facilities parental support guidance for learning at home. The importance of direct parental involvement in learning is because, ideally, early childhood learning is carried out together, where parents must be directly involved in the learning. This is done as a way to motivate children to be able to do assignments or follow the lessons that have been given by the teacher well.

When we consider the current state of parents, it is clear that some find it difficult to engage in learning activities with their children due to their hectic work schedules that require them to manage their time effectively. This is also demonstrated in the research of Andika Sari, 2017; Khadijah, 2020, who discovered that a busy working mother typically meets her child when the child is about to sleep or has already fallen asleep. The school's or teacher's role is thus necessary to provide understanding to parents for them to overcome the obstacles they face. The synergy between parents' free time and their children's desire to learn is critical to BDR's success. Parents' constraints should always be communicated to teachers in order for them to find solutions. Thus, teachers must always be prepared to assist parents. Parents are the first supporters of BDR learning. When viewed from a variety of angles, it is clear how parents should educate their children.

Apart from their efforts to accompany their children to school, parents can also allow their children to choose the time they will complete the teacher-assigned tasks. Additionally, parents must assist children in completing teacher-assigned activities or assignments and may even provide rewards when the child completes learning activities. Children occasionally require parental encouragement when they become bored with the learning activities they are engaged in. As a result, parents must always be present when their child completes teacher-assigned work. Parents play a critical role in learning at home, according to Menheere \& Hooge, who assert that parental involvement has a significant impact on children's success. According to Akbar (2017), parental involvement provides children with internalised experiences into the child's personality. The requirement for complete parental support for effective home-based learning is a form of collaboration between parents and teachers. 


\section{CONCLUSION}

A good relationship between teachers and parents was discovered following research on how to improve teacher-parent collaboration in the implementation of Learning from Home for early childhood during the pandemic. Teachers and parents have shared the WAG learning mechanism with each other, indicating that this is the case (Whatsapp group). The teacher's instructions on WAG will make it easier for parents to accompany their children as they learn at home. Teachers and parents had a positive attitude toward communicating in the implementation of LFH, as WhatsApp Groups are a place for two-way communication in the LFH process. In addition, teachers use the WAG to communicate with students' parents, such as asking students' and parents' news and distributing learning materials.

Parental involvement in the implementation of LFH is reflected in parents' attitude who can ensure that their children are safe and comfortable while learning. There is no pressure on children to follow the learning process because parents always encourage their children to be enthusiastic about it. The most effective way for parents to participate in their children's education and play is by coordinating their free time with their children's interests in learning activities. Because of this synergy, BDR is extremely effective. It is a sign of parent-teacher collaboration when parents tell their children's teachers when they have problems. Parents will greatly benefit from the teacher's response. Children's positive attitude toward their teacher's assignments was also evident when parents accompanied them. Parents are among the earliest proponents of BDR education. Parents who give their children the freedom to complete the assignments given by the teacher demonstrate this positive attitude. Parents' efforts in motivating their children play a major role in these attitudes. The school should have a guidebook for the implementation of LFH learning so that parents of students can assist their children in learning from home to be implemented at home. This communication should be improved and systematic. It is easier for teachers to help parents with problems they are having with their children's education if they have access to daily notes from both the teacher and the student's parents.

\section{REFERENCES}

Andika Sari, D. (2017), Children's Gross Motor: After School Activities and Mothers Role at Home (a Survey Study of Kindergarthen Group A, at Pondok Aren District, Tangerang Selatan, Banten Province, Indonesia). https://doi.org/10.2991/icece-16.2017.86

Aguswinarti. 2020. Implementasi Parenting pada Pendidikan Anak Usia Dini di Masa Pandemi Covid19. Jurnal Pendidikan Pembelajaran Pemberdayaan Masyarakat. VoII. No. 2 September 2020.

Ariyani, T. (2016). Pentingnya Pendidikan Anak Usia Dini bagi Tumbuh Kembang Anak. Jurnal Dinamika Pendidikan Dasar, 8 (1), 50-58

Creswell JW. 2010. Research Design. Pendekatan Kualitatif, Kuantitatif dan Mixed. Sabran B Penerjemah : Maulana A. Hardani W, editor. Yogyakarta : Pustaka Pelajar. Terjemahan dari : Research Desugn:Qualitative and Mixed Method Approaches.

Hutami, M.S., \& Nugrahei, A.S. (2020). Evolving a Facilitation Process Towards Students Centred learning: A Case Study in Computing. Journal of Information Systems Education, 18(4), 459468.

Khadijah dan Media Gusman. 2020. Pola Kerjasama Guru dan Orangtua Mengelola Bermain Anak Usia Dini Selama Masa Pandemi. Jurnal Kumata Cendekia.Vol. 8. No. 2. Bulan Juni 2020.

Khadijah, K. (2020). Pola kerja sama guru dan orangtua mengelola bermain AUD Selama masa pandemi COVID-19. Kumara Cendekia, 8(2), 154-170.

Haerudin. dkk. (2020). Peran Orangtua dalam Membimbing Anak Selama Pembelajaran di Rumah sebagai Upaya Memutus COVID-19. Karawang: Universitas Singa Perbangsa Karawang

Lilawati, A. (2020). Peran Orang Tua dalam Mendukung Kegiatan Pembelajaran di Rumah pada Masa Pandemi. Jurnal Obsesi: Jurnal Pendidikan Anak Usia Dini, 5(1), 549. https://doi.org/10.31004/obsesi.v5i1.630

Menheere, A., \& Hooge, E. (2010). Parental involvement in children's education: $A$ reviewstudy about the effect of parental involvement on children's school education with a focus on the position of illiterate parents. Journal of the 
European Teacher Education Network JETEN, 6(January 2010), 157

Masnipal. (2013). Siap Menjadi Guru dan Pengelola PAU Profesional. Jakarta: PT. Gramedia

Oni Taliawo. dkk (2019). Hubungan Kerjasama antara Orangtua dan Guru dalam Meningkatkan Minat Belajar Siswa di SMPN 1 Atap Desa Buo Kecamatan Looda, Halmahera, Maluku Utara. ISSN: 1979-0481. Vol. 12, No. 4

Oktaria, R., \& Putra, P. (2020). Pendidikan anak dalam keluarga sebagai strategi Pendidikan Anak Usia Dini saat pandemi COVID-19. Jurnal Ilmiah Pesona PAUD, 7(1), 41-51.

Pramana, C. (2020). Pembelajaran Pendidikan Anak Usia Dini di Masa Pandemi COVID-19. Indonesian Journal of Early Childhood: Jurnal Dunia Anak usia Dini, 2 (2), 115-124. https://doi: 10.35473/ijec.v2i2.557.

Safitri, Husnaina Mailisa, 2012, Pengaruh Gaya Kepemimpinan, Kerjasama Tim, dan Gaya Komunikasi Terhadap Kepuasan Kerja serta Dampaknya Terhadap Kinerja Pegawai pada Sekretariat Daerah Kota Sabang, Jurnal Manajemen ISSN 2302- O199 Pascasarjana Universitas Syiah Kuala 17 Pages pp. 1-171 - Volume 2, No. 1, November 2012

Simpson, R. D. S. T. T., \& Tinggi, E. S. B. S. S. 2021. Kerjasama Orang Tua Dan Guru Dalam Pembelajaran Paud Di Masa Pandemi COVID-19. Jurnal Vox Dei. Volume 2. Nomor 1. Juni 2021

Suharsimi Arikunto. 2005. Prosedur Penelitian suatu Pendekatan Publik. Jakarta : PT. Rineka Cipta.

Satrianingrum, A. P., Yulsyofriend., \& Ismet, S. (2020). Metode Pengenalan Bahasa Inggris di Pioneer Montessori School Padang. Diklus: Jurnal Pendidikan Luar Sekolah, 2 (4), 101-111.

Wardati, L., Husna, N., Khairunisa, A., \& Lubis, H. (2020). Pola Kerjasama Guru Dan Orang Tua Pada Masa Pandemi Covid 19 Di RA Masjid Agung Medan Polonia. Al-Ulum: Jurnal Pendidikan Islam, 1(2).

Wardani, A., \& Ayriza, Y. (2020). Analisis kendala orang tua dalam mendampingi anak belajar di rumah pada masa pandemi Covid-19. Jurnal Obsesi: jurnal Pendidikan anak usia dini, 5(1), 772.

https://www.kemdikbud.go.id/main/blog/2020/o5/kemendikbud-terbitkan-

pedoman-penyel enggaraan-belajar-dari -rumah 
This page is intentionally left blank 